\title{
Smoking habits and attitudes among university students in Palestine: a cross-sectional study
}

\author{
S.G. Musmar ${ }^{7}$
}

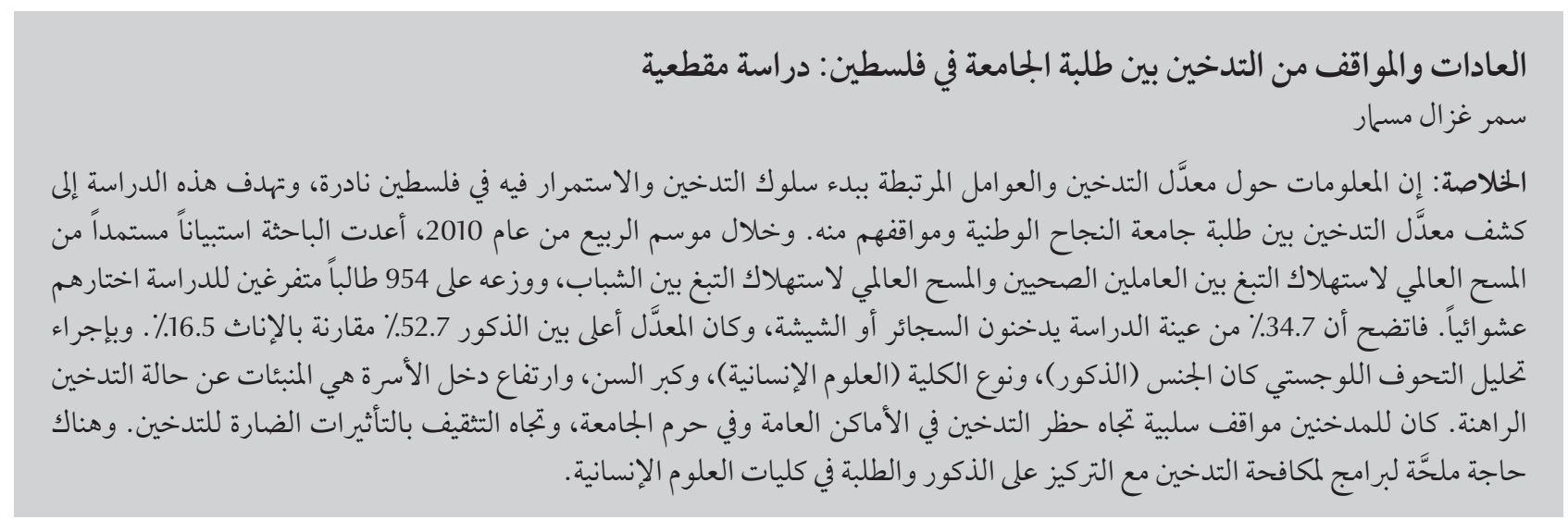

ABSTRACT Information about the rate of smoking and factors associated with initiating and maintaining the behaviour is scarce in Palestine. The aim of this study was to explore the rate of and attitudes towards smoking among An-Najah National University students. During spring 2010, a questionnaire adopted from the Global Health Professionals Survey and the Global Youth Tobacco Survey was administered to 954 randomly selected full-time students. Overall $34.7 \%$ of the study sample were cigarette or waterpipe smokers, and this rate was higher among males than females (52.7\% versus 16.5\%). In logistic regression analysis, sex (male), type of college (humanities), older age and higher family income were predictors of current smoking status. Smokers had more negative attitudes to banning smoking in public areas on campus and to education about the harmful effects of smoking. Antismoking programmes with special attention to males and students in humanities are badly needed.

\section{Étude transversale sur le tabagisme et les attitudes des étudiants de niveau universitaire en Palestine}

RÉSUMÉ Les informations sur le pourcentage de fumeurs et sur les facteurs associés à l'initiation au tabagisme puis à son maintien sont rares en Palestine. La présente étude visait à connaître le taux de fumeurs chez des étudiants de I'Université nationale An-Najah et leur attitude vis-à-vis du tabagisme. Au cours du printemps 2010, un questionnaire issu de l'enquête mondiale sur les professionnels de santé et l'enquête mondiale sur le tabagisme chez les jeunes a été administré à 954 étudiants à temps plein sélectionnés aléatoirement. Au total, 34,7 \% de l'échantillon de l'étude étaient des fumeurs de cigarettes ou de pipes à eau, et ce pourcentage était plus élevé chez les hommes que chez les femmes (52,7\% contre 16,5\%). Dans une analyse de régression logistique, le sexe (masculin), le type de faculté (lettres et sciences humaines), un âge plus élevé et un revenu familial supérieur étaient des facteurs prédictifs du statut de fumeur actif. Les fumeurs avaient des attitudes plus négatives au sujet de l'interdiction du tabac dans les zones publiques du campus et de l'éducation sur les effets nocifs du tabac. Des programmes antitabac portant une attention spéciale aux hommes et aux étudiants en lettres et sciences humaines sont sérieusement nécessaires. 


\section{Introduction}

Tobacco use is the leading preventable cause of death worldwide [1]. Tobacco use continues to kill more than 5 million people worldwide each year, and this number is expected to grow [2]. According to the latest estimates more than $80 \%$ of the 8.3 million tobaccoattributable deaths in 2030 will occur in low to middle-income countries [1].

Although the most serious health outcomes associated with smoking typically emerge later in life, studies have shown that the earlier individuals begin to smoke, the higher their risk for cancer, heart disease, stroke, chronic obstructive lung disease [3], nicotine addiction [4] and possibly their risk of developing anxiety disorders and depression $[5,6]$. According to the Palestinian Central Bureau of Statistics (PCBS), the youth proportion of Palestine is as high as $27 \%$ [7]. Although PCBS has also reported a high rate of smoking among youth (19.8\%) [8], information on smoking and factors associated with initiating and maintaining such behaviour in this group in Palestine is very limited. The aim of this study therefore was to explore the rate of and attitudes to smoking behaviour among students at An-Najah University in Nablus. The results of such a study are expected to provide data to inform specific interventions tailored to this important and vulnerable group.

\section{Methods}

After obtaining approval from the institutional review board of An-Najah National University, this cross-sectional study was carried out during the spring semester of the 2009-10 academic year.

\section{Sample}

The study cohort consisted of full-time students enrolled at An-Najah National University. Our objective was to recruit about $5 \%$ of all registered full-time students $(n=17521)$ in the 16 faculties at the university. Taking into consideration the percentage of types of colleges and sex, 1000 students from all faculties were selected from the university register using stratified randomization and were invited to participate in the survey. Of the 1000 students approached, 960 students agreed to participate and filled the questionnaire; 6 questionnaires were discarded because they were incorrectly filled (overall response rate 95.4\%).

\section{Data collection}

Anonymous self-administered questionnaires were handed to students by research assistants during breaks between lectures and were collected after 10-20 minutes. Students gave verbal consent after being assured that participation was voluntary, their identity was not recorded on the questionnaire, all data would be used for research purposes only and there was no penalty for non-participation.

\section{Questionnaire}

A 4-component (48-item) smokinguse questionnaire was used to collect information on select demographic variables, participants' opinions about smoking behaviour, smoking habits of smokers and knowledge and attitude of all participants towards smoking. The questionnaire was developed in Arabic from relevant instruments used for the assessment of tobacco use, including the Global Health Professionals Survey and the Global Youth Tobacco Survey $[9,10]$. The average time needed to complete the questionnaire was 10 minutes.

The first 8 items (sociodemographic profile) covered age, sex, marital status, residence, type of college, level of study, family income and smoking status (both cigarette and waterpipe). All participants answered 8 questions about their opinions of smoking habits, reasons for practising and not practising the habit, banning smoking at home and banning it in public areas. Smokers answered 8 questions about their smoking habits (their first smoking attempt, amount, type and duration of smoking, smoking expenses, smoking cessation attempts and their willingness to quit smoking). Overall knowledge and attitude towards the effect of smoking on health were measured by 12 questions about positive attitudes and 12 questions about negative attitudes. The negative attitude questions asked about knowledge of harmful irreversible effects of smoking on general health, pregnancy, its relationship to cancer, heart disease, general lifespan and the effect of passive smoking. The positive attitude questions asked about beliefs and myths of the benefits of smoking and doubts about the evidence for its harmful effects. Each question was answered on a 5-point Likert scale. The average score out of 10 for all positive attitude questions and all negative was given for every participant (i.e. a raw score out of 60 which was transformed to out of 10).

The Arabic version questionnaire items were evaluated by 4 faculty members in the field of health for accuracy, relevance, and appropriateness. The questionnaire was then pilot tested for wording and clarity on 30 university students who were not part of the sample and it was modified accordingly. Cronbach alpha was used to measure the internal consistency of the questionnaire, which was 0.79 for the opinion of all participants about smoking habits, 0.81 for smoking habits of smokers and 0.93 for knowledge and attitude.

\section{Definitions}

Smoking status was established in accordance with World Health Organization criteria for cigarette smoking and the criteria set by Maziak et al. for waterpipe smoking $[11,12]$. Smokers were subjects who at the time of the survey smoked either regularly $(\geq 1$ cigarette/day or $\geq 1$ waterpipe/week) or occasionally $(<1$ cigarette a day or $<1$ waterpipe/week). Nonsmoker 
control students had never smoked at the time of the survey.

According to PCBS data average family income in Palestine was about US\$ 500 [13], therefore the family income item was divided into low (US\$ < 300/month), average (US\$ 300-600/ month) and high (US\$ $>600 /$ month).

\section{Statistical analysis}

Data on all components of the questionnaire were entered and analysed using Minitab, software version 14. Descriptive statistics were used to show the demographic profile of the study sample. Binary logistic regression analysis was used to examine the association between smoking and factors such as age, sex, study level, college and income. Correlations between smoking behaviour and attitudes and beliefs towards smoking were analysed using the chi-squared test; $t$-test and 1-way analysis of variance (ANOVA) were applied for the comparison of positive and negative attitudes. All results were considered statistically significant at $P$ $\leq 0.05$.

\section{Results}

Table 1 summarizes the overall demographic characteristics of the 954 students (480 male and 474 females) participating in the study. The mean age was 20.5 (standard deviation 1.1) years, with males and females almost equal ages. More students (57.1\%) were enrolled in the arts and humanities colleges than in sciences $(35.9 \%)$ or health care (7.0\%). The great majority of students were single (92.7\%) and living with their parents (73.5\%), and about half the students' families (51.9\%) had average income.

The total number of students who reported that they smoked was 331 (34.7\%). The rate was higher among males than females (52.7\% versus $16.5 \%)$, older than younger students (39.3\% versus $28.9 \%$ ) and among students living in dormitories compared with those living with their families ( $40.3 \%$ versus $32.7 \%$ ). By college the highest rate was among students of the humanities and arts (41.1\%) (Table 1).

Table 2 details factors that were associated with being a smoker. Since smokers were coded as 1 and

\begin{tabular}{|c|c|c|c|c|c|}
\hline \multirow[t]{2}{*}{ Characteristic } & \multirow{2}{*}{$\begin{array}{c}\text { Total } \\
\text { No. }\end{array}$} & \multicolumn{2}{|c|}{ Smokers } & \multirow[t]{2}{*}{$x^{2-t e s t}$} & \multirow[t]{2}{*}{$P$-value } \\
\hline & & No. & $\%$ & & \\
\hline Sex & & & & 138.3 & $<0.01$ \\
\hline Male & 480 & 253 & 52.7 & & \\
\hline Female & 474 & 78 & 16.5 & & \\
\hline Age (years) & & & & 10.3 & $<0.01$ \\
\hline $18-20$ & 425 & 123 & 28.9 & & \\
\hline$>20$ & 529 & 208 & 39.3 & & \\
\hline College & & & & 27.4 & $<0.01$ \\
\hline Arts and humanities & 545 & 224 & 41.1 & & \\
\hline Sciences & 342 & 82 & 23.9 & & \\
\hline Health & 67 & 25 & 37.3 & & \\
\hline Study level & & & & 0.039 & NS \\
\hline Junior (years 1 or 2 ) & 347 & 119 & 34.3 & & \\
\hline Senior (years 3+) & 607 & 212 & 34.9 & & \\
\hline Martial status & & & & 0.501 & NS \\
\hline Married & 70 & 27 & 38.6 & & \\
\hline Single & 884 & 304 & 34.4 & & \\
\hline \multicolumn{6}{|l|}{ Residence } \\
\hline With family & 701 & 229 & 32.7 & 4.8 & $<0.05$ \\
\hline Dormitory & 253 & 102 & 40.3 & & \\
\hline Family income (per month) & & & & 3.29 & NS \\
\hline Low $(<$ US\$300) & 114 & 31 & 27.2 & & \\
\hline Average (US\$300-600) & 495 & 175 & 35.6 & & \\
\hline High (> US\$ 600) & 345 & 125 & 36.2 & & \\
\hline Total & 954 & 331 & 34.7 & & \\
\hline
\end{tabular}

$N S=$ not significant . 


\begin{tabular}{lccccc}
\hline \multicolumn{7}{l}{ Table 2 Relationship between demographic factors and smoking among university students $(\boldsymbol{n}=\mathbf{9 5 4})$} \\
\hline Factor & $\boldsymbol{\beta}$ & $\mathrm{SE}$ & Z-value & $\boldsymbol{P}$-value & OR (95\% CI) \\
Age & 0.47 & 0.22 & 2.18 & 0.029 & $1.62(1.05-2.49)$ \\
Sex & -2.55 & 0.21 & -11.85 & $<0.001$ & $0.08(0.05-0.12)$ \\
College & -0.57 & 0.14 & -3.95 & $<0.001$ & $0.56(0.42-0.75)$ \\
Study level & -0.39 & 0.22 & -1.73 & 0.084 & $0.68(0.43-1.05)$ \\
Residence & 0.33 & 0.17 & 1.89 & 0.058 & $1.39(0.99-1.96)$ \\
Marital status & 0.51 & 0.31 & 1.65 & 0.100 & $1.67(0.91-3.10)$ \\
Income & 0.27 & 0.12 & 2.26 & 0.024 & $1.32(1.04-1.68)$ \\
\hline
\end{tabular}

$\beta=$ estimated coefficient $; S E=$ standard error $; O R=$ odds ratio; $C I=$ confidence interval .

nonsmokers as 0 , the odds ratio $(\mathrm{OR})$ denotes the probability of being a smoker for each of the demographic variables included in the logistic regression model (after being validated using different goodness-of-fit tests). The standard cut-off value of 0.5 was used for all variables. There was a strong statistically significant association of smoking with sex (male) and type of college (humanities) $(P<0.001)$. Income (average and high income) and age ( $>20$ years) were also statistically significant predictors of smoking $(P$ $<0.05)$. There was no significant association between risk of smoking and residence, marital status or study level (junior or senior).

Table 3 summarizes the attitudes of smokers and nonsmokers towards smoking behaviour and the banning of smoking at home or in public places. Compared with nonsmokers more of the smokers had a positive attitude towards smoking ( $54.0 \%$ versus $5.4 \%$ ) $(P<0.05)$ and its use for recreational purposes (45.0\% versus $15.7 \%)(P$ $<0.05)$. The study showed that peer pressure and smoking as a way of "proving manhood" were seen by more nonsmokers as possible reasons for smoking. More of the smokers would allow smoking in their household than would the nonsmokers (34.4\% versus $6.9 \%)(P<0.05)$. More of the smokers would allow their children to smoke than would the nonsmokers $(28.7 \%$ versus $4.0 \%)(P<0.05)$. Finally, fewer smokers than nonsmokers agreed that smoking should be banned in public places (52.3\% versus $85.4 \%)(P$ $<0.05)$.

Table 4 shows a summary of students' scores for knowledge about the effect of smoking on health. Most students had above-average knowledge about the negative effect of smoking on health, which wasstatistically significant in favour of nonsmokers compared with smokers and females compared with males. However, there was no significant differences according to the type of college. Viewing the effect of smoking on health positively was significantly more common for smokers than nonsmokers and males than females. The college of art students also scored higher than those in science and health in their view of the positive effect

\begin{tabular}{|c|c|c|c|c|c|c|c|c|}
\hline \multirow[t]{2}{*}{ Item } & \multicolumn{2}{|c|}{ Total } & \multicolumn{2}{|c|}{ Smokers } & \multicolumn{2}{|c|}{ Nonsmokers } & \multirow[t]{2}{*}{$x^{2}$-test } & \multirow[t]{2}{*}{$P$-value } \\
\hline & No. & $\%$ & No. & $\%$ & No. & $\%$ & & \\
\hline $\begin{array}{l}\text { Do you agree with smoking } \\
\text { behaviour?a }\end{array}$ & 213 & 22.3 & 179 & 54.0 & 34 & 5.4 & 288.1 & $<0.001$ \\
\hline Why do students smoke? ${ }^{b}$ & & & & & & & 138.8 & $<0.001$ \\
\hline Recreation & 247 & 25.9 & 149 & 45.0 & 98 & 15.7 & & \\
\hline Proving manhood & 335 & 35.1 & 73 & 22.0 & 262 & 42.0 & & \\
\hline Peer pressure & 140 & 14.6 & 14 & 4.2 & 126 & 20.2 & & \\
\hline Other reasons & 232 & 24.3 & 95 & 28.7 & 137 & 22.0 & & \\
\hline $\begin{array}{l}\text { Would you allow smoking in your } \\
\text { household? a }\end{array}$ & 157 & 16.4 & 114 & 34.4 & 43 & 6.9 & 113.2 & $<0.001$ \\
\hline $\begin{array}{l}\text { Would you allow your children to } \\
\text { smoke in the future? }{ }^{\text {a }}\end{array}$ & 120 & 12.6 & 95 & 28.7 & 25 & 4.0 & 119.8 & $<0.001$ \\
\hline $\begin{array}{l}\text { Do you agree with banning } \\
\text { smoking in public areas? }\end{array}$ & 705 & 73.8 & 173 & 52.3 & 532 & 85.4 & 121.6 & $<0.001$ \\
\hline
\end{tabular}

${ }^{a}$ Affirmative answer.

${ }^{b}$ Respondents could select more than 1 reason. 


\begin{tabular}{|c|c|c|c|c|c|c|}
\hline \multirow[t]{2}{*}{ Factor } & \multicolumn{3}{|c|}{ Negative attitudes } & \multicolumn{3}{|c|}{ Positive attitudes } \\
\hline & Mean (SD) score & $t$ or $F$-value & $P$-value & Mean (SD) score & $t$ or $F$-value & $P$-value \\
\hline Smoking & & -12.57 & $<0.001$ & & 5.65 & $<0.001$ \\
\hline Smokers & $7.4(1.6)$ & & & $6.2(1.8)$ & & \\
\hline Nonsmokers & $7.9(1.1)$ & & & $4.7(1.5)$ & & \\
\hline Sex & & 4.75 & $<0.001$ & & 5.1 & $<0.001$ \\
\hline Male & $7.6(1.5)$ & & & $5.6(1.8)$ & & \\
\hline Female & $7.9(1.1)$ & & & $4.9(1.6)$ & & \\
\hline College & & 2.56 & 0.06 & & 1.65 & 0.192 \\
\hline Arts and humanities & $7.8(1.4)$ & & & $5.4(1.9)$ & & \\
\hline Sciences & $7.6(1.3)$ & & & $5.1(1.6)$ & & \\
\hline Health care & $7.7(0.9)$ & & & $5.0(1.5)$ & & \\
\hline
\end{tabular}

$t$ is the value of Student $t$-test, and $F$ is the value of 1-way ANOVA test. $S D=$ standard deviation.

of smoking on health, although this did not reach statistical significance.

In a sub-analysis of smoking behaviour among the different colleges ( $\mathrm{Ta}-$ ble 5), a higher percentage of smokers in the humanities college started smoking before age 15 years compared with the other 2 colleges ( $40.4 \%$ versus $23.1 \%$ and $20.0 \%$ respectively). The duration of smoking and the number of cigarettes smoked per day only become statistically significantly different after the first year of smoking and when the number of cigarettes exceeded 3 per day. Finally, the desire to stop smoking, attempts to stop smoking and willingness to accept help to stop smoking were similar between the 3 groups.

\begin{tabular}{|c|c|c|c|c|c|c|c|c|c|c|}
\hline \multirow[t]{2}{*}{ Item } & \multicolumn{2}{|c|}{$\begin{array}{l}\text { Arts and } \\
\text { humanities } \\
(n=225)\end{array}$} & \multicolumn{2}{|c|}{$\begin{array}{l}\text { Sciences } \\
(\boldsymbol{n}=\mathbf{8 1})\end{array}$} & \multicolumn{2}{|c|}{$\begin{array}{l}\text { Health care } \\
\qquad(n=25)\end{array}$} & \multicolumn{2}{|c|}{$\begin{array}{c}\text { Total } \\
(n=331)\end{array}$} & \multirow[t]{2}{*}{$x^{2}$-test } & \multirow[t]{2}{*}{$P$-value } \\
\hline & No. & $\%$ & No. & $\%$ & No. & $\%$ & No. & $\%$ & & \\
\hline $\begin{array}{l}\text { Age of first cigarette smoking? } \\
\text { (years) }\end{array}$ & & & & & & & & & 12.6 & 0.01 \\
\hline$<15$ & 91 & 40.4 & 19 & 23.1 & 5 & 20.0 & 115 & 34.7 & & \\
\hline 15-18 & 81 & 36.0 & 38 & 46.3 & 16 & 64.0 & 135 & 40.8 & & \\
\hline$>18$ & 53 & 23.6 & 24 & 29.2 & 4 & 16.0 & 81 & 24.5 & & \\
\hline $\begin{array}{l}\text { How long you have been } \\
\text { smoking? (years) }\end{array}$ & & & & & & & & & 7.78 & 0.25 \\
\hline$<1$ & 38 & 16.9 & 9 & 11.1 & 3 & 12.0 & 50 & 15.1 & & \\
\hline $1-3$ & 84 & 37.3 & 31 & 38.3 & 15 & 60.0 & 130 & 39.3 & & \\
\hline$>3-5$ & 56 & 24.9 & 19 & 23.5 & 3 & 12.0 & 78 & 23.5 & & \\
\hline$>5$ & 47 & 20.9 & 22 & 27.1 & 4 & 16.0 & 73 & 22.1 & & \\
\hline How much do you smoke? & & & & & & & & & 12.27 & 0.05 \\
\hline$<3$ cigs/day & 58 & 25.8 & 15 & 18.5 & 5 & 20.0 & 78 & 23.5 & & \\
\hline 4-10 cigs/day & 56 & 24.9 & 20 & 24.7 & 11 & 44.0 & 87 & 26.3 & & \\
\hline 1 pack/day & 72 & 32.0 & 34 & 42.0 & 9 & 36.0 & 115 & 34.7 & & \\
\hline$>1$ pack/day & 39 & 17.3 & 12 & 14.8 & 0 & 0.0 & 51 & 15.5 & & \\
\hline $\begin{array}{l}\text { Do you think about } \\
\text { quitting smoking? }\end{array}$ & 139 & 62.0 & 50 & 61.7 & 13 & 52.0 & 202 & 61.0 & 1.04 & 0.59 \\
\hline $\begin{array}{l}\text { Did you try to stop } \\
\text { smoking? }\end{array}$ & 116 & 52.0 & 46 & 57.0 & 14 & 56.0 & 176 & 53.0 & 1.05 & 0.59 \\
\hline $\begin{array}{l}\text { Will you accept help to } \\
\text { quit smoking? }\end{array}$ & 152 & 68.0 & 50 & 61.7 & 16 & 64.0 & 218 & 66.0 & 0.703 & 0.71 \\
\hline
\end{tabular}




\section{Discussion}

The response rate to the questionnaire (95.4\%) indicated a high degree of willingness by the students to participate in the study. The age and sex distribution of the participants was also comparable to the general university population which has almost equal proportions of male and female students.

Our results showed a high selfreported rate of smoking among university students; $34.7 \%$ of the overall study sample ( $52.7 \%$ among males and $16.4 \%$ among females). These figures are higher than the PCBS estimates of the proportion of smokers in the general Palestinian population which was 19.8\% (37.0\% among males and $2.2 \%$ among females) [8]. Compared with university students in Arab countries, our Palestinian students had a higher rate compared with Jordanian (28.6\%) [14] and Saudi (17.5\%) students [15] but lower than Lebanese (40\%) students [16].

Although many more males than females smoked, the percentage of female students smoking was much higher than the rate of smoking among women in the general population [8]. The rising rate of smoking among women in Arab countries has been a focus for several studies, especially the increasing use of waterpipe smoking among young women. For example, an Egyptian study investigating behavioural and sociodemographic factors associated with tobacco use among female university students in Cairo found an urgent need to correct a misperception that waterpipe smoking is safer and less harmful than cigarette smoking [17]. Waterpipe smoking is known to be popular in the Nablus area among both males and females, which might explain the high rate of smoking among female university students at An-Najah University.

The study showed that most smokers were over 20 years of age. A reason for that may be the family pressure against smoking during adolescence. Once students get older and acquire more freedom, family pressure lessens. This is consistent with the findings of Gfroerer et al,, who showed that among a sample of college students in the United States, those who lived with their parents were less likely to have smoked in the last month compared with students who did not [18]. However, there was no statistically significant association between students' age or the years they spent in university and their tendency to smoke.

This study found a significantly higher risk of smoking among students in the arts and humanities field compared with students enrolled in the sciences or in health care. The lower risk of smoking by health sciences students is probably due to the strong effect of education about the health risks of smoking. We have no explanation for the intermediate risk in students in the science schools. Similar findings were observed in a Saudi study in Abha that compared smoking between college of education and college of medicine students [15], and a Syrian study that found that the rate of smoking was lower among medical students [19].

The negative effects of smoking seemed to be perceived by all students; however, more smokers and male students perceived positive effects compared with nonsmokers and females. This finding is consistent with a Jordanian study that looked at knowledge and attitude towards smoking among Jordan University of Science and Technology students [14]. This reflects the tendency to defend one's behaviour despite knowledge of its risk and might also reflect a greater tendency of women to care for their own health and that of others. "Recreation" was the main reason for smoking according to most of the current smokers, followed by "proving manhood". Nonsmokers, however, believed that their peers smoked mainly to prove their manhood and popularity. In other, similar studies "curiosity" was believed to be the main reason for smoking [15].

In this study, the attitudes of students towards smoking were different among smokers and nonsmokers. Smokers tended to be more tolerant of smoking and its role as a recreation activity. Moreover, smokers were more tolerant toward smoking at home and would be less likely to put pressure on their children not to smoke. Smokers also were less enthusiastic about banning smoking in public places.

Although this study had some important findings regarding the factors affecting smoking in a young population, the findings cannot be generalized to all young people in Palestine since the study sample included only university students.

\section{Conclusion}

This study shows that the self-reported rate of smoking among students at AnNajah National University was higher than previous estimates for the rest of the Palestinian population. An antismoking programme including health education and extensive counselling on the harmful effect of smoking is needed at this university for both male and female students, with special attention to students in the humanities colleges.

\section{References}

1. Mathers CD. Loncar D. Projection of global mortality and burden of disease from 2002 to 2030. PLoS Medicine, 2006, 3:e442.
2. WHO report on the global tobacco epidemic 2009. Implementing smoke-free environments. Geneva, World Health Organization, 2009. 
3. Davis JW et al. Passive smoking affects endothelium and platelets. Archives of Internal Medicine, 1989, 149:386-389.

4. Taioli E, Wynder EL. Effect of the age at which smoking begins on frequency of smoking in adulthood. New England Journal of Medicine, 1991, 325:968-969.

5. Goodman E, Capitman J. Depressive symptoms and cigarette smoking among teens. Pediatrics, 2000, 106:748-755.

6. Johnson JG et al. Association between cigarette smoking and anxiety disorders during adolescence and early adulthood. Journal of the American Medical Association, 2000, 284:23482351.

7. Youth in Palestinian territory: statistical indicators. On the occasion of the International Youth Day 12 August 2008. Palestinian Central Bureau of Statistics [online factsheet] (http://www. pcbs.gov.ps/Portals/_pcbs/PressRelease/shabab2008.pdf, accessed 15 March 2012).

8. On the eve of World Day to Stop Smoking, May 31, the PCBS issues a press release about the prevalence of smoking in the Palestinian Territory [press release]. Palestinian Central Bureau of Statistics, 31 May 2009 (http://www.pcbs.gov.ps/Portals/_pcbs/PressRelease/smoking\%20English.pdf, accessed 29 February 2012).

9. The Global Youth Tobacco Survey (GYTS). World Health Organization [website] (http://www.who.int/tobacco/surveillance/gyts/en/, accessed 15 March 2012).

10. The Global Health Professional Survey (GHPS). World Health Organization [website] (http://www.who.int/tobacco/surveillance/ghps/en/, accessed 15 March 2012).
11. Maziak W et al. Standardizing questionnaire items for the assessment of waterpipe tobacco use in epidemiological studies. Public Health, 2005, 119:400-404.

12. Guidelines for controlling and monitoring the tobacco epidemic. Geneva, World Health Organization, 1998.

13. Press release on Labour Force Survey results (January-March, 2010) Round [press release]. Palestinian Central Bureau of Statistics, 18 May 2009 (http://www.pic-palestine.ps/userfiles/ file/pdfs/labour_force_survey_en.pdf, accessed 29 February 2012).

14. Haddad LG, Malak MZ. Smoking habits and attitudes towards smoking among university students in Jordan. International Journal of Nursing Studies, 2002, 39:793-802.

15. Abolfotouh MA et al. Smoking habits of King Saud University students in Abha. Annals of Saudi Medicine, 1998, 18:212-216.

16. Hala Tamim et al. Tobacco use by university students in Lebanon. Addiction, 2003, 98:933-939.

17. Labib $\mathrm{N}$ et al. Comparison of cigarette and water pipe smoking among female university students in Egypt. Nicotine and Tobacco Research, 2007, 9:591-596.

18. Gfroerer JC, Greenblatt JC, Wright DA. Substance use in the US college-age population: differences according to educational status and living arrangement. American Journal of Public Health, 1997, 87:62-65.

19. Almerie $M Q$ et al. Cigarettes and waterpipe smoking among medical students in Syria: a cross-sectional study. International Journal of Tuberculosis and Lung Disease, 2008, 12:1085-1091. 